\title{
A missional study of Ghanaian Pentecostal churches' leadership and leadership formation
}

\begin{tabular}{|c|c|}
\hline \multicolumn{2}{|l|}{$\begin{array}{l}\text { Author: } \\
\text { Peter White }{ }^{1}\end{array}$} \\
\hline $\begin{array}{l}\text { Affiliation: } \\
{ }^{1} \text { Department } \\
\text { of Religion an } \\
\text { Faculty of The } \\
\text { University of } \\
\text { South Africa }\end{array}$ & $\begin{array}{l}\text { f Science } \\
\text { d Missiology, } \\
\text { ology, } \\
\text { retoria, }\end{array}$ \\
\hline $\begin{array}{l}\text { Note: } \\
\text { Dr Peter Whit } \\
\text { postdoctoral r } \\
\text { of Prof. Nelus } \\
\text { Head of Depa } \\
\text { Science of Rel } \\
\text { Missiology of } \\
\text { of Theology, } \\
\text { Pretoria, Pretc } \\
\text { Africa. }\end{array}$ & $\begin{array}{l}\text { is a } \\
\text { esearch fellow } \\
\text { Niemandt, } \\
\text { rtment of } \\
\text { igion and } \\
\text { the Faculty } \\
\text { Iniversity of } \\
\text { oria, South }\end{array}$ \\
\hline $\begin{array}{l}\text { Corresponder } \\
\text { Peter White }\end{array}$ & ce to: \\
\hline $\begin{array}{l}\text { Email: } \\
\text { pastor_white }\end{array}$ & @hotmail.com \\
\hline $\begin{array}{l}\text { Postal addres } \\
\text { Private Bag X2 } \\
0028 \text {, South A }\end{array}$ & $\begin{array}{l}\text { s: } \\
\text { 0, Hatfield } \\
\text { frica }\end{array}$ \\
\hline $\begin{array}{l}\text { Dates: } \\
\text { Received: } 21 \\
\text { Accepted: } 21 \\
\text { Published: } 11\end{array}$ & $\begin{array}{l}\text { Vov. } 2014 \\
\text { Feb. } 2015 \\
\text { June } 2015\end{array}$ \\
\hline $\begin{array}{l}\text { How to cite th } \\
\text { White, P., } 201 \\
\text { study of Ghan } \\
\text { Pentecostal ch } \\
\text { leadership an } \\
\text { formation', HT } \\
\text { Studies/Theol } \\
71(3), \text { Art. \#28 } \\
\text { http://dx.doi. } \\
\text { hts.v71i3.2865 }\end{array}$ & $\begin{array}{l}\text { is article: } \\
5 \text { 'A missional } \\
\text { aian } \\
\text { urches' } \\
\text { d leadership } \\
\text { 'S Teologiese } \\
\text { ogical Studies } \\
\text { 365, } 8 \text { pages. } \\
\text { org/10.4102/ } \\
\end{array}$ \\
\hline $\begin{array}{l}\text { Copyright: } \\
\text { (C) 2015. The A } \\
\text { Licensee: AOS } \\
\text { OpenJournals } \\
\text { licensed unde } \\
\text { Commons Att } \\
\text { License. }\end{array}$ & $\begin{array}{l}\text { Authors. } \\
\text { IS } \\
\text { This work is } \\
r \text { the Creative } \\
\text { ribution }\end{array}$ \\
\hline 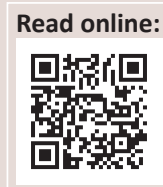 & $\begin{array}{l}\text { Scan this QR } \\
\text { code with your } \\
\text { smart phone or } \\
\text { mobile device } \\
\text { to read online. }\end{array}$ \\
\hline
\end{tabular}

Church leadership plays an important and irreplaceable role in the planting and the configuration of the missional congregation. The key to the formation of missional communities is their leadership. In that regard, this article explores Classical Ghanaian Pentecostal Churches' leadership and leadership formation from a missiological perspective. This was done through an exposition on their leadership system (structure). It was argued that Classical Ghanaian Pentecostal Churches' leadership is based on the Fivefold Ministry (Apostle, Prophet, Evangelist, Pastor and Teacher). These leadership functions were therefore discussed in the light of their missiological implication. The conclusion arrived at is that it is not enough to discover one's spiritual gift or calling; these gifts should be developed and nurtured through mentoring and proper theological education, with the ultimate purpose being to participate in the Missio Dei.

\section{Introduction}

Leadership is the process of influencing the thoughts, emotions and behaviours of followers towards set goals (Dessler 2012:34). This implies that leadership is very important in every area of life. Church leadership, in this regard, plays an important and irreplaceable role in the planting and configuration of the missional congregation. The key to the formation of missional communities is their leadership (Roxburgh 1998:183). Missional leadership, in this article, refers to a kind of church leadership that trains and leads their congregation to participate in the Missio Dei by joining in with the Holy Spirit to discern what God is doing in their context. Missional leaders are always on the move, hastening to the ends of the earth, beseeching all to be reconciled to God (Kim 2009:256). Missional leaders transform people and institutions, under the guidance of the Holy Spirit, to participate in God's mission (Breedt \& Niemandt 2013:8).

In view of the aforementioned statements, a literature search on Pentecostalism in Ghana revealed that very little is known about Ghanaian Pentecostal leadership, and leadership formation and its missiological implication. This research gap therefore led me to investigate and discuss this phenomenon from a missiological perspective. The objective of this article is to explore Classical Ghanaian Pentecostal Churches' understanding of church leadership, leadership systems or structures, leadership formation and its missiological implication. The methodologies employed for the study included interviews and a literature study on Pentecostalism in Ghana, as well as some ecumenical documents (i.e. documents published by the World Council of Churches (WCC) and the Lausanne documents). The research scope would therefore be limited to the three main Classical Pentecostal Churches (i.e. Christ Apostolic Church International, The Apostolic Church, Ghana, and The Church of Pentecost).

\section{Classical Ghanaian Pentecostal Churches' leadership: Gifts of the Holy Spirit}

Leadership is an organisational challenge, and the nature of the church determines the nature of appropriate leadership (Breedt \& Niemandt 2013:8). Missional leadership is found in the faith community: 'a community of persons who, in a variety of ways and with a diversity of functional roles and titles, together practices missional authority' (Van Kooten \& Barrett 2004:139). Pentecostals' understanding of leadership starts with the kind of spiritual gift possessed by individuals, and how it has been developed. An important element of the Pentecostal movement is the emphasis on the 'gifts of the Spirit', which is often expressed in their literature as 'Charismatic gifts' (Asamoah-Gyadu 2005:7). Contemporary manifestations of Pentecostalism are often classified in terms of 'charismatic renewal' as a result of their general orientation towards the restoration of the gifts of the Holy Spirit (which include speaking in tongues, prophesy, healing, experiencing visions and revelations) to the heart of people 
(Asamoah-Gyadu 2013:5). When interviewed on 01 October 2013, Apostle Joseph Sakyi ${ }^{1}$ stated that:

\begin{abstract}
In Ghanaian Pentecostals' theology, the infilling of the Holy Spirit - which is oftentimes followed by speaking in tongues - is not the end goal of one's spirituality. It is rather a way leading to the Holy Spirit endowment for ministry within the church and mission to the world. Members are therefore encouraged to continue seeking deeper experiences of the Holy Spirit's endowment, by identifying their ministry gifts for the edification of the church and for mission. In their understanding, mission is everybody's responsibility and there is no way one could be involved in mission without being gifted by the Holy Spirit to play a specific part.
\end{abstract}

The Third Lausanne Congress on World Evangelization (2010) is of the following view:

The church is called to witness for Christ today by sharing in God's mission of love through the transforming power of the Holy Spirit. The Spirit fills the Church with His gifts, which must be eagerly desired as the indispensable equipment for Christian service. The Spirit gives power for mission and for the great variety of works of service. Without the gifts, guidance and power of the Spirit, our mission is mere human effort. And without the fruit of the Spirit, our unattractive lives cannot reflect the beauty of the gospel. (p. 10)

Similarly, the WCC states that (Lorke \& Werner 2013:56), 'the Holy Spirit gives gifts freely and impartially which are to be shared for the building up of others and the reconciliation of the whole creation'. The Christ Apostolic Church International (2015), in this regard, sees the diverse manifestations of spiritual gifts as God's way of 'division of labour' in the church. The Holy Spirit distributes these gifts of the Spirit as he sees fit for each and every believer (Wagner 1994b:39). These gifts are the attestation of the empowering of the Holy Spirit and are vital as the signs and wonders of ministry. They serve as spiritual empowerment that equips one for ministry both within and outside the body of Christ. These gifts are the tools which enable one to fulfil the ministry required (Wimber 1986:146). They are the trans-rational manifestations of God. They are trans-rational in the sense that God, at his own discretion, anoints each person for an effect that he wants to produce (Fee 1994:151-160). At his annual Iron Sharpens Iron Ministers Conference held at Qodesh, Lighthouse Chapel International, on 25 July 2012, Bishop Heward-Mills (2012) submits that, 'God would never send you without endowing you with gifts, abilities, grace, and the anointing to accomplish the task He has assigned you for'.

In spite of the view that all of the gifts are accorded equal respect and recognition, in Classical Ghanaian Pentecostal Churches' view, these gifts can be grouped into two major categories, namely 'leadership gifts' and 'supportive gifts'. According to the tenet of the Apostolic Church, Ghana (2015), the leadership gifts are also described as the Fivefold Ministry, including Apostle, Prophet, Evangelist, Pastor and Teacher, with the rest of the gifts serving as supporting gifts. According to Roxburgh (1998:206), the Apostolic, Prophetic and Pastoral offices of the church are leadership gifts. Their call is to direct and lead their congregation towards their missional context. A further elaboration of this view will be discussed later.

\section{The Fivefold Ministry}

Classical Ghanaian Pentecostal Churches' understanding of leadership is in the concept of the Fivefold Ministry. Although this term cannot be found in the Bible, it has been accepted in many Pentecostal theological discourses on church leadership. DeSilva (2004) writes:

Ephesians 4:11-16 articulates a healthy model for ministry, one that needs to be universally grasped and enacted if the church hopes to keep up with the needs of the world. (p. 731)

Some writers view the gifts of Apostle, Prophet, Evangelist, Pastor and Teacher as offices (Wagner 1994b:39), whilst others view them as functions (Fee 1994:707; Hirsch 2006:153; Witherington 2007:290-291). When Pentecostals talk about the Fivefold Ministry, they are referring to the Apostle, Evangelist, Prophet, Pastor and Teacher. In their view, the Fivefold Ministry is the five leadership or governmental offices given to the church by Jesus Christ for the edification of the church and for the purpose of church administration and decisions on doctrinal and spiritual issues of the church.

Classical Ghanaian Pentecostal Churches' leadership structure can be seen in Figure 1.

This Pentecostal idea will be elaborated on further in the subsequent subheadings. My submission at this point is that the ministry of Apostle, Pastor, Prophet, Teacher and Evangelist in Ephesians 4:7 and 11-12 is not just for church leadership, but for the entire church (cf. Eph 4:7; 11). It is argued that:

Leadership in the light of Apostle, Pastor, Prophet, Teacher, and Evangelist can be conceived as a 'calling within a calling'. It is a distinct task that entails leading and influencing, and not just ministering. (Hirsch 2006:171)

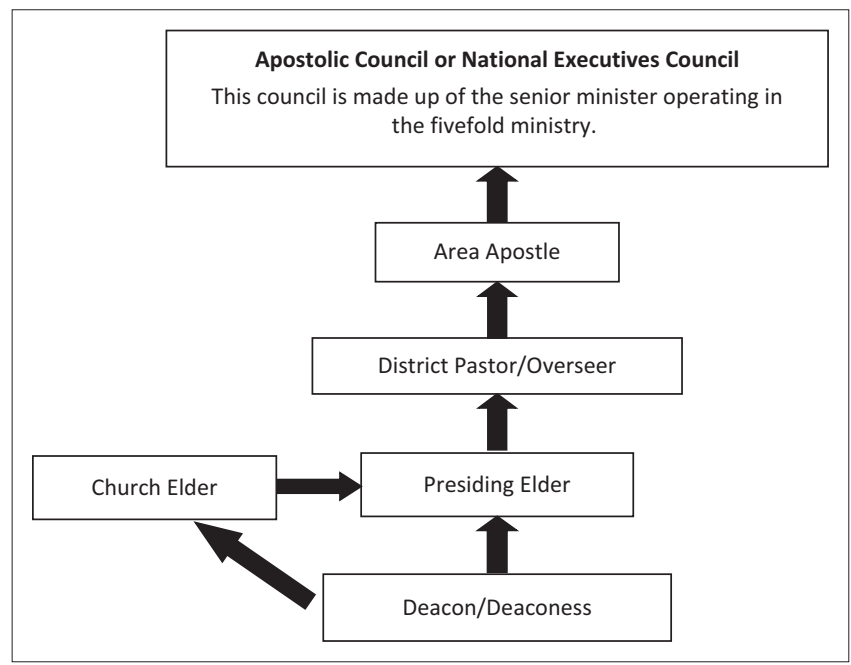

Source: Author's own work.

FIGURE 1: Structure of the Classical Ghanaian Pentecostal Churches leadership. 


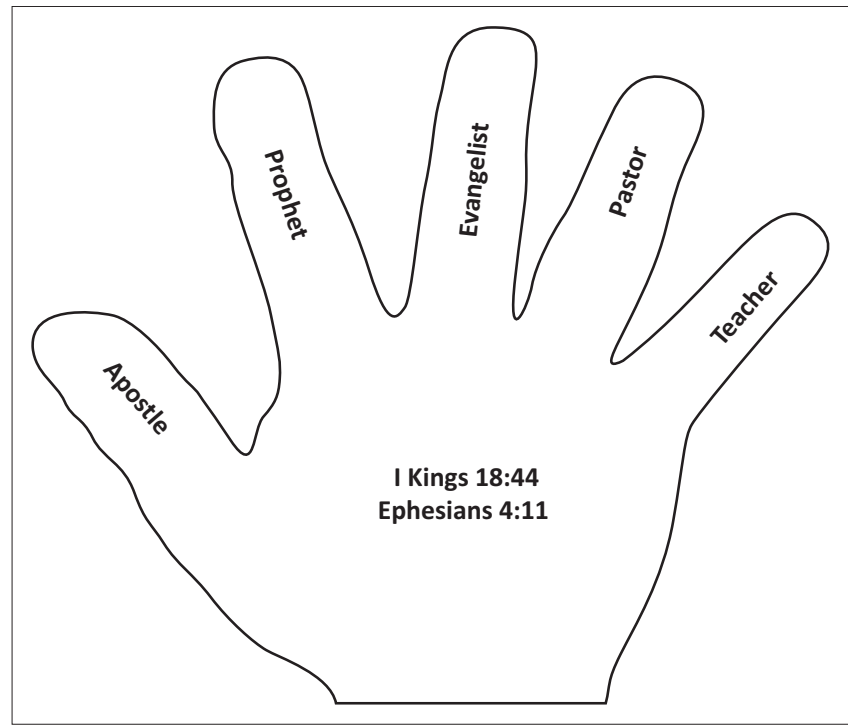

Source: Author's own work.

FIGURE 2: Fivefold Ministry.

In his presentation at the New Communities and Fresh Expressions Church Conference organised by the Department of Science of Religion and Missiology, Faculty of Theology, University of Pretoria, at the Nederduitse Gereformeerde Kerk Moreleta Park, Hirsch (2014) states that we cannot reach maturity without the Fivefold Ministry working together in the church. They are the missional ministries that generate missional energy.

Many Ghanaian Pentecostals figuratively present the Fivefold Ministry by identifying them with the five fingers of the hand (Figure 2), for the hand is seen as an object of leadership, direction, authority, order, power and warning.

\section{Apostle}

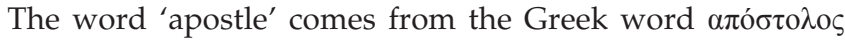
which means 'a messenger, envoy, ambassador, or the one sent forth with orders' (Danker, Arndt \& Gingrich 2000:2122). It refers to one who has a delegated authority by another in a foreign land (Duffield \& Van Cleave 2008:351; Fee 1994:191). Wagner (1994b:231) describes an Apostle as one who assumes and exercises general leadership over a number of churches with an extraordinary authority in spiritual matters that is spontaneously recognised and appreciated by those churches. Apostles, as examples, have been used by church pastors and leaders for missional help and guidance (Wagner 1994b:42). Church history tells us that Apostles were the first leaders of the church; they were commissioned by Jesus to initiate and direct the preaching of the gospel (Roxburgh 1997:62). Although the majority of Christians agree that the title 'apostle' is reserved for those amongst the first generation of Christians, many Christian denominations continue in one way or another to recognise a continuing apostolic ministry. Many churches believe in the doctrine of apostolic succession (e.g. the Roman Catholic Church and the Eastern Orthodox Churches), which holds that properly ordained bishops are the successors to the
Apostles (Encyclopaedia Britannica n.d.; cf. International Theological Commission 1979). Other Christian groups, such as Classical Pentecostals, consider the role of a missionary to be fulfilling an apostolic ministry (Duffield \& Van Cleave 2008:353). The WCC (Lorke \& Werner 2013:18) argues that apostolic succession in ministry, under the guidance of the Holy Spirit, is intended to serve the apostolicity of the church.

Hirsch $(2006: 76-77 ; 155)$ suggests that there are three primary functions of the apostolic ministry, namely to:

- embed missional DNA through pioneering new ground for the gospel and church. He defines Missional DNA as the intrinsic, reproducible, central guiding mechanism necessary for the reproduction and sustainability of genuine missional movements

- guard missional DNA through the application and integration of apostolic theology

- create the environment in which the other ministries are able to emerge.

Furthermore, an Apostle could be a senior Pastor of a local church, but does not necessarily have to restrict himself to the work of a pastor; for there are Pastors, Presiding Elders, and Elders that work with him to shepherd the church body (Wagner 1994b:42). This is similarly what happens in the three main Classical Pentecostal Churches in Ghana. In Classical Ghanaian Pentecostal Churches, an Apostle is an overseer of either a district or a region. Apart from his administrative oversight, he also plans and lays out strategies for evangelistic activities such as crusades, church planting and training of mission workers. When interviewed on 20 December 2013, the current Chairman of the Church of Pentecost, Apostle Dr Opoku Onyinah, argues, according to the position of The Church of Pentecost, that:

The gifts and office of the apostle are first in the church, because the apostles, as we have seen, are foundation stones. Inspired apostolic teaching is the foundation upon which the church rests. But the apostles are also those who are sent into the world with the message of the gospel. Barnabas, who shared the missionary task, is called an apostle along with Paul. Barnabas did not share the foundational calling of the twelve, but he did share their evangelistic labours (Ac 14:14). As we recognize the missionary dimension of all church offices, the outreach of the church can be seen to include not only the evangelist to preach the gospel, but the use of every gift of the Spirit by the widest range of gifted Christians. The fellowship of the Spirit that binds Christians together also calls and equips them to be Christ's envoys to the ends of the earth. The gift of apostleship in the church today equips one to go where Christ directs in order to establish, instruct, and guide local assemblies of believers.

Presenting his view (based on the Constitution of the Christ Apostolic Church International) in a personal interview on 01 October 2013, Apostle Joseph Sakyi states that, administratively, the Apostolic offices are mainly occupied by the Chairman, General Secretary, and the five other members of the National Executive, namely the Fields Director, Missions 
Director, Evangelism Director, Christian Education Director and the Prophetic Director. Other Apostles, although not members of the National Executive Board, are the Territorial Apostles who are responsible for the various territories demarcated by the church. According to the WCC (Lorke \& Werner 2013:128), the church is apostolic. The Father sent the Son to establish the church. The Son, then, chose and sent the Apostles and Prophets, empowered with the gifts of the Holy Spirit at Pentecost, to serve as its foundation and to oversee its mission. The Christian community is called to be ever faithful to these apostolic origins. In a similar vein, Hirsch (2006:7677) argues that every Holy Spirit-birthed believer in Jesus Christ has full missional DNA, and therefore has direct access to the power of Apostolic Genius. This therefore implies that the church is not only gifted with a small section of people who are to perform in the apostolic office (ministry) as it is the case in the Pentecostal Churches - but rather that every believer in Jesus Christ has an apostolic assignment.

\section{Prophet}

The Hebrew word for 'prophet' נביא It connotes one who acts as a spokesman for God. In the time of Samuel another word, 'seer' (ראל), began to be used as well, reoccurring seven times in reference to Samuel. After this another word, חזֶ ['seer'], was employed. In 1 Chronicles 29:29 all three these words are used: 'Samuel the seer (רואה), Nathan the Prophet (נביא), Gad the seer (זָזָ)'. In Joshua 13:22, Balaam is called נְחָזלָמי ['deviner'], a word used only for a false prophet (Douglas \& Tenney 1987:823). Prophets are primarily preachers of righteousness, but sometimes they foretell the future. Prophecy is one of the gifts of the Spirit and those who have and exercise this gift persistently are called Prophets. Being a Prophet goes beyond the simple display of the gift of prophecy. It is accompanied by supernatural signs (visions, dreams and trances), an inward voice and the unusual visitation of the presence and power of God (Freeman 1981:14; Kaiser \& Silva 2007:139).

The WCC (Lorke \& Werner 2013:71) states that evangelism is a prophetic vocation which involves speaking truth to power in hope and love; for example, in the Old Testament, Prophets speak for God in order to build up the body and make them prosper in all they do (2 Chr 20:20). Numbers 12:6 says: 'When a Prophet of the LORD is among you, I reveal myself to him in visions; I speak to him in dreams'. Amos 3:7 says: 'Surely the Sovereign LORD does nothing without revealing his plan to his servants the Prophets'. Their ministry includes, but is not limited to, exhortation and strengthening of believers; proclaiming God's judgement on all injustice (Lorke \& Werner 2013:42-43; 75); ensuring that the holiness of God is honoured and truth is respected (Hirsch 2006:158); and directing the path in which the church should travel (Wagner 2000:97).

According to the Christ Apostolic Church International's Constitution $(2000: 54 ; 67)$, the prophetic ministry has been established as one of the arms of the National Executive offices in the church to seek God's directions for the church as well as to ensure that the prophetic covenant of the church is being adhered to by the National Executive Council. The office is contested by senior ministers of the church every four years at the General Council meeting. Legibility is basically senior ministers' capability to hold that office with the approval of Pastors who can attest to the person's prophetic ability in the past. Larbi (2001:286) submits that prophecies were given to warn people of the Second Advent in The Church of Pentecost. Furthermore, much of the mission and major decisions of the church were directed through prophetic utterances. According to The Church of Pentecost's Constitution:

Whereas those endowed with the gift of prophecy amongst the clergy and laity is allowed to exercise their gift in any church meetings, it is only those ordained into the office of prophet among the clergy who have the authority to give directive prophecies for the church. (Church of Pentecost's Constitution 2010:14)

The WCC (Lorke \& Werner 2013:15) posits that Christians are called to be a prophetic people, bearing witness to God's word; a priestly people, offering the sacrifice of a life lived in discipleship; and a royal people, serving as instruments for the establishment of God's reign. Furthermore, the Church, as the body of Christ, acts by the power of the Holy Spirit to continue his life-giving mission in prophetic and compassionate ministry, thereby participating in God's work of healing a broken world (Lorke \& Werner 2013:8).

\section{Evangelist}

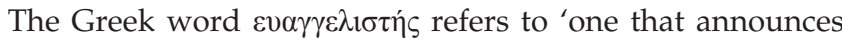
or spreads the good news of God's kingdom' (Danker et al. 2000:403). Although Christians are all charged to do the work of an Evangelist, there are, however, believers who have specifically been called to the ministry of evangelism. Evangelists are mobile ministers (Moreau 2000:346), for they are not confined in service to one spot but move about to different localities, preaching the good news concerning Jesus Christ to those who have not heard the message before (Hirsch 2006:170). Evangelists attract crowds because of the ability they are endowed with to perform signs and wonders.

In Ghana, although it is common to see people in public places preaching and claiming to be Evangelists, many such people do not belong to a local church. They only preach outside and take their offerings from the public without being accountable to any church. In order to control the intruding of such 'evangelists' and their activities on churches, many of the Classical Pentecostal Churches have reserved the title 'Evangelist' for members of the National Executive Council or regarded it as a 'higher calling' after a proven ministry as a Pastor. It is very scarce to hear the title being used amongst the members and leaders of local Classic Pentecostal Churches, even though they may be doing the work of an Evangelist. Amongst Ghanaian Pentecostals, although every believer is assigned the duty of evangelising, the office of the Evangelist is seen differently from the general call to believers to evangelise. Those who are accorded this title by 
the church are those who have served in that capacity for a long time and the fruit of their ministry can be testified to by the entire leadership and members of the church (The Church of Pentecost's Constitution 2010:43-44).

\section{Pastor}

The Hebrew and Greek words translated as 'Pastor' in the Scriptures are רֶוֹ 'shepherd' (Douglass \& Tenney 1987:721). The calling of a Pastor is that of a shepherd: to attend to, feed and guard the sheep or flock of God. A Pastor is an overseer of a number of God's people. Pastors give proper attention to people and are accessible to these people (Hirsch 2006:170). They offer counselling and prayer, and restore lost souls. Pastors must possess, amongst others, the qualities highlighted in 1 Timothy 3:1-7 and live an exemplary life.

In Classical Ghanaian Pentecostal Churches, Pastors are in charge of local congregations. In some circumstances, a Pastor can be appointed to be in charge of a district (an administrative area created within most Pentecostal Churches in Ghana), and is then given the title 'District Pastor'. His work is to help his congregation through the teaching and preaching of the word of God; included in the pastoral calling are the house fellowship leaders as well as youth leaders. In the three main Classic Pentecostal Churches (i.e. Christ Apostolic Church International, the Apostolic Church of Ghana and The Church of Pentecost), pastoral care in local churches is left in the hands of Presiding Elders of the various local churches and later report to the District Pastor activities going on in the various local churches, as well as seek advice on how to run their churches. In this context, only the District Pastor uses the title 'Pastor'.

\section{Teacher}

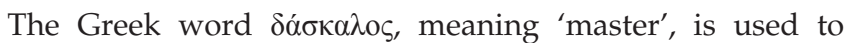
connote a Teacher in the Scriptures (Danker et al. 2000:240241); Jesus was given this title in John 3:2. Hence, a Teacher is a specially called person who imparts instruction and communicates knowledge of the word of God as if he is the author of the Bible. A Teacher illuminates Scripture with a number of revelations and truth discoveries. He discovers and makes clear hidden truths and latent power behind the word of God, and he is never boring to listen to (Hirsch 2006:170). Although a Pastor or Elder has more responsibilities than teaching alone, teaching must be their first priority (1 Tm 3:2; Tt 1:9).

A person with the gift of teaching is identifiable by two distinct characteristics: he will have a keen interest in the personal study of the Word and in the disciplines involved in studying the Scriptures. He will also have the capacity to communicate clearly the truths and applications of the Word, so others may learn and profit (McRae 1976:48). Amongst Ghanaian Pentecostals, those who are identified as having the gift of teaching (or show the ability of teaching) are mostly put in charge of the Christian education of the church, popularly known as Sunday school. This position could be in a local church, at district, regional or national level, depending on the capacity of the person and the available vacancies. However, not all people who do the work of teaching are allowed to use the title 'Teacher'; only the Christian Education Director is allowed the use of the title. This approach is mostly the case in Classic Pentecostal Churches.

The person, who assumes the office of a National Director of Christian Education, is mostly the one who, in conjunction with the leadership of the church, prepares teaching materials (such as Sunday school manuals and devotional books) for discipleship. He also sometimes organises training programmes for those who are in charge of Christian education at regional, district and local levels to acquaint them with the teachings and doctrines of the church.

\section{Missiological implication of Ghanaian Pentecostal Churches' Fivefold Ministry leadership}

However, for the sake of administrative and ecclesiological order (authority), Ghanaian Pentecostal Churches have separated the manifestation and operations of the gifts of the Holy Spirit into leadership gifts and supportive gifts in their churches; none of these gifts are perceived as not useful for missiological purposes. The Apostle Paul clarified this with his analogy of the working of the human body as a way of understanding how the manifestations of the gifts of the Holy Spirit operate in the church. The ultimate purpose of God's blessing of believers with spiritual gifts is for ministry within the church, mission to the world, and church growth (Green 1972:67).

Missiologically, in Ghanaian Pentecostals' understanding, the gift of the Apostle is seen as a missionary gift for church planting and the training of other leaders to take care of any and/or all newly planted and/or existing churches. The office of the Prophet is recognised for revealing the purposes and plans of God to the church in their mission outreach. The office of the Evangelist is for the propagation of the gospel (although every believer is assigned to evangelise); the Pastoral and the Teaching offices are for discipleship, and are seen as mostly intertwined, due to the criteria presented in 1 Timothy 3:2. Frost and Hirsch (2003:165-181) coined the acronym APEPT in reference to the missional functions of five ministries in the church. In their view (Frost \& Hirsch 2003:165-181), apostolic function usually pioneers new missional works and oversees their development. Prophetic function discerns the spiritual realities in a given situation and communicates them in a timely and appropriate way to further the mission of God's people. Evangelistic function communicates the gospel in such a way that people respond in faith and discipleship. Pastoral function shepherds the people of God by leading, nurturing, protecting, and caring for them. Teaching function communicates the revealed wisdom of God so that the people of God learn how to obey all that Christ has commanded them. 
Woodward (2012:111) calls missional leaders who occupy these five functions the 'five culture creators'. He describes the five culture creators as the equippers. According to Woodward (2012:121), Apostles are the dream awakeners as they live out their calling, and they create a discipleship lifestyle and call people to participate in advancing the kingdom of God. Prophets are the heart revealers or displayers: they pursue God's shalom and call the church to God's new social order and stand with the poor and the oppressed. Evangelists incarnate and proclaim the good news. Pastors are called the soul healers. They seek the wholeness and the holiness, and they cultivate life-spirituality in the community and bring reconciliation. Teachers are the light givers. They explain the sacred Scriptures and their destination is the immersion of God's people in Scripture and dwelling faithfully in God's story (Woodward 2012:121-167). The Fivefold Ministry comprises the gifts that God bestowed to the church and constitute the missional or apostolic leadership needed for the custody of its missional nature, the development and the maturation of the church as it participates in the mission of God in the world. The apostolic ministries instil or communicate the missional DNA to all the members of the entire body so that the missional church may keep its unity and create and develop missional ministries in context (Hirsch 2006:152). Anderson posits that:

A missional church in all of its expressions must have missional leadership, and missional leaders must have a missional imagination. There is no missional church without a missional imagination, which discerns what God is up to in the world, imagines possible ways to be involved in that mission, and invites people to take action. Missional leaders invite, encourage, equip, guide, and partner with others in discerning God's mission. (Anderson 2008:194)

Missional imagination is the capacity to think, to reflect on mission and on ways of being missional in a given context or on ways to participate in that mission. It gives the momentum to discern what God is up to in the context and to join him in the mission. I wish to state at this point that, no matter the kind of gift one is given, it must be nurtured and developed. Jesus Christ did not send his disciples out until he saw that they had enough training or education from him. This therefore leads us to leadership and ministerial formation of Classical Ghanaian Pentecostal Churches.

\section{Leadership and ministerial formation}

From a biblical perspective, discipleship has a link with missional leadership formation (Walls \& Ross 2008:35); for example, many of the disciples of Jesus Christ became people who pioneered the spreading of the gospel during the time of Jesus Christ and during the period of the Apostles. Although not every disciple will become a leader, discipleship serves as an essential part of the missional leadership formation of the church. The answer to leadership failure is not just more leadership training, but better discipleship training. Leaders must first be disciples of Christ himself. This means that authentic Christian leaders must be like Christ in having a servant heart, humility, integrity, purity, lack of greed, prayerfulness, dependence on God's Spirit, and a deep love for people (Third Lausanne Congress on World Evangelization 2010:36). This inner transformation experienced by the leader is the realisation that leadership is nothing more than a function of the church; the true identity of the church is discipleship (Roxburgh 1998:183).

Wagner (1994a:28) argues that the second vital sign of a growing churchisawell-mobilised laity.Furthermore, Wagner (1994a:20) reports that 'many churches have confirmed that the most important institutional variable for the growth and expansion of the local church is leadership'. Van Rheenen (1996:164) articulates that congregational nurturing must always be preceded or coupled with leadership training. In the midst of this congregational nurturing, God raises leaders and places them in the body, just as he wants them to be. The key to the formation of missional communities is their leadership. Church leadership formation is therefore fundamentally important for the missiological purpose in the world (Guder 1998:183; 185).

In spite of the view that leadership formation is important to mission, Sweet (2004:169) contends that leadership is not only about the leader. Leadership also includes those who have chosen or agreed to follow the leader. According to Breedt and Niemandt (2013):

Leadership is shared interdependently in a body. With God as the head, the body works together, serving and protecting. The body metaphor of Romans 12 has already been used to illustrate the interrelatedness of members of the Christian community and represents the best example of "body parts" fulfilling a function and even a leadership role when needed. Body parts therefore need each other to be a functional part of the body. (p. 5)

I think this should be at the heart of missional leadership formation. Leadership formation amongst Classical Ghanaian Pentecostal Churches can be put in the context of informal and formal leadership formation.

\section{Informal leadership formation: In the church}

This approach indicates more of a mentoring role or a kind of apprenticeship. I will call it a relational missional leadership formation. Relational leadership formation in this context refers to a kind of missional leadership formation which is done through interpersonal relationship, observation and serving a senior person or a leader. This could be related to Jesus' approach in Mark 3:13-15, and Apostle Paul's relationship with Timothy and Titus in their leadership formation. This system of leadership formation is more practical than theoretical.

In this approach, Classical Ghanaian Pentecostal Churches do not really consider the educational background of the people involved. Local churches are responsible for this kind of training. Depending on how committed one is to the development of his or her ministry gift, the concept or process 
moves from membership to church worker, to Deacon (Ac 6) or Deaconess (Rm 16), to Elder, and then Presiding Elder. At all these levels, formal education - whether secular or theological - is not necessarily required; however, it is considered a plus when one has it. The focus here is on developing people's ministry gifts and placing them in positions within the church where they can function optimally. In many cases, people are placed under the mentorship of other senior church workers or leaders. Amongst the Classic Pentecostal Churches, the farthest a woman can go up the leadership ladder is to the office of 'Deaconess'. This, however, does not prevent women from national leadership positions which are not part of positions that are about the Fivefold Ministry. The ministerial training policy of The Church of Pentecost (2013), recommended the need to strengthen and create an environment in which women with ministry gifts will be developed to assist in Church services as Deaconess, and the creation of ministry opportunities for them in all areas. Although this was the approach for leadership formation in Ghanaian Classical Pentecostal Churches, many of these churches have currently included formal leadership and educational training, especially, for those who can read and write English.

\section{Formal leadership formation: Theological education}

The mission of the church on Earth is to serve the mission of God, and the mission of theological education is to strengthen the mission of the church. Theological education serves to (Third Lausanne Congress on Evangelization 2010:45):

- train those who lead the church as Apostles, Prophets, Evangelists, Pastors and Teachers, equipping them to teach the truth of God's Word with faithfulness, relevance and clarity

- equip all God's people for the missional task of understanding and relevantly communicating God's truth in every cultural context.

Until recently, many Ghanaian Pentecostal Churches did not pay much attention to theological education; initially they saw it as unspiritual. Some would even go as far as saying that, 'even the Apostles of Jesus Christ were not educated, but they were still used by God. What you need is the anointing' (Asamoah-Gyadu 2005:126). Some of them were of the view that theological training makes one unspiritual. However, this view is gradually diminishing. It was initially so because many of their former ministers had little or no formal education. Their emphasis was then on the Spirit factor and one's ministry gift. Vision 2013 of The Church of Pentecost outlined the importance of theological education in contemporary ministerial leadership formation:

The ministry is challenged by the dynamics and trends of the contemporary environment. This, therefore, calls for a constant upgrading and increasing of knowledge and skills in modern trends for all ministers. To be more effective in today's ministry is to engage in life-long learning processes, which are sharpened through prayer. Provision therefore needs to be made for relevant resources and training opportunities for the ministers. Hands-on training also needs to continue. Since this generation may be the last link between the old and the new, the task of the present leadership, amongst other things, is to 'apostolize' those ministers who did not have the opportunity to rub shoulders with the founding leaders within the modern context. (The Church of Pentecost 2013)

The WCC also share their view on the importance of theological education in their statement:

A church without proper and qualified theological education systems tends to diminish itself or ends in Christian religious fundamentalism. A church with properly developed theological education qualifies itself for greater degrees of interaction and outreach to the different levels and challenges in its society, as well as to a deeper commitment to holistic Christian mission. (Lorke \& Werner 2013:116)

The WCC (Lorke \& Werner 2013:113) therefore called for a massive quality improvement in training of missionaries, which should be drastically upgraded in academic level and enlarged in terms of the disciplines covered; by intentionally moving beyond denominational lines in theological education and promoting the establishment of centralised mission colleges jointly supported by different denominations and mission agencies. The introduction of formal theological training in Classical Ghanaian Pentecostal Churches has brought many benefits. It has enabled them to produce missional leaders, equipped for various contexts and cultures. This has also made it possible for them to send missionaries to various countries and places to serve as bivocational, and fulltime missionaries. Missional leadership formation, in this regard, should have Missio Dei as an essential component (Doornenbal 2012:199). Missional leadership cannot exist if Missio Dei is not part of the responsibility of the leaders. The purpose of missional leadership formation is to form and equip people who will participate in the Missio Dei and also equip their congregation to do same through the help of the Holy Spirit (Roxburgh 1998:183-220). The end product of missional leadership formation is to:

- develop people whose ministry is flowing out of a vibrant spiritual life

- model a Christ-like character

- mentor people in the practices and habits of the Christian life

- cultivate a high view of what God can do

- understand culture of their context

- engage the culture of their context

- prioritise the kingdom of God over the church as an organisation.

\section{Conclusion}

Leadership is an organisational challenge, and the nature of the church determines the nature of appropriate leadership (Breedt \& Niemandt 2013:8). Pentecostals' understanding of leadership starts with the kind of spiritual gift one possesses, and how it has been developed. Classical Ghanaian Pentecostal Churches' understanding of leadership is in 
the concept of the Fivefold Ministry (i.e. Apostle, Prophet, Evangelist, Pastor and Teacher). The Fivefold Ministry was therefore discussed in the light of Ghanaian Pentecostal understanding and broader Ecumenical discourse, as well as their missiological implication. Missiologically, it was noted that apostolic function, usually pioneers new missional works and oversees their development. Prophetic function discerns the spiritual realities in a given situation and communicates them in a timely and appropriate way to further the mission of God's people. Evangelistic function communicates the gospel in such a way that people respond in faith and discipleship. Pastoral function shepherds the people of God by leading, nurturing, protecting, and curing them. Teaching function communicates the revealed wisdom of God so that the people of God learn how to obey all that Christ has commanded them.

It was also argued that no matter the kind of gift one possesses, it must be nurtured and developed. This therefore led to the discussion of Ghanaian leadership formation in the light of formal and informal leadership formation. It was stated that the formal leadership has to do with proper theological education, and the informal boils down to a more practical or an apprentice approach. I finally submit that the end goal of missional leadership formation is to develop people whose ministry is flowing out of a vibrant spiritual life; modelling Christ-like character; and mentoring their congregation to participate in the Missio Dei.

\section{Acknowledgements \\ Competing interests}

The author declares that he has no financial or personal relationships which may have inappropriately influenced him in writing this article.

\section{References}

Anderson, D.R., 2008, 'Missional DNA of the Evangelical Lutheran Church in America', in C. Van Gelder (ed.), pp. 194, The missional church \& denominations: Helping congregations develop a missional identity, William B. Eerdmans Publishing Company, Grand Rapids, MI.

Asamoah-Gyadu, K.J., 2005, African charismatics: Current development within independent indigenous Pentecostalism in Ghana, Brill, Leiden.

Asamoah-Gyadu, K.J., 2013, Contemporary Pentecostal Christianity: Interpretation from an African context, Regnum Books International, Eugene, OR.

Breedt, J.J. \& Niemandt, C.J.P., 2013, 'Relational leadership and the missional church', Verbum et Ecclesia 34(1), Art. \#819, 9 pages. http://dx.doi.org/10.4102/ ve.v34i1.819

Christ Apostolic Church International, 2000, Our tenets, viewed 24 March 2015, from http://cacihq.org/our-tenents

Christ Apostolic Church International, 2015, Constitution, CAC Printing Press, Accra.

Danker, F.W., Arndt, W.F. \& Gingrich, F.W., 2000, A Greek-English lexicon of the New Testament and other early Christian literature, 3rd edn., University of Chicago Press, Chicago, IL.

DeSilva, D.A., 2004, An introduction to the New Testament: Contexts, methods \& ministry formation, InterVarsity Press, Downers Grove, IIL.

Dessler, G., 2012, Supervision and leadership in a changing world, Pearson Education, n.p., NJ.

Doornenbal, R., 2012, Crossroads: An exploration of the emerging missional conversation with a special focus on 'missional leadership' and its challenges for theological education, Eburon Academic Publisher, Delft.
Douglas, J.D. \& Tenney, M.C. (eds.), 1987, The new international dictionary of the Bible, Zondervan Publishing House, Grand Rapids, MI.

Duffield, G.P. \& Van Cleave, N.M., 2008, Foundations of Pentecostal theology, Foursquare Media, Los Angeles, CA.

Encyclopaedia Britannica Online n.d., Apostolic succession, viewed 19 February 2015, from http://www.britannica.com/EBchecked/topic/30289/apostolic-succession

Fee, G.D., 1994, God's empowering presence: The Holy Spirit in the letters of Paul, Hendrickson Publishing Inc., Peabody, MA.

Freeman, H., 1981, Introduction to Old Testament prophets, 15th edn., Moody Publishers, Chicago, IL.

Frost, M. \& Hirsch, A., 2003, The shaping of things to come: Innovation and mission for the 21st century church, Hendrickson Publishers Inc., Peabody, MA.

Green, H.L., 1972, Why churches die, Bethany Fellowship, Minneapolis, MN.

Guder, D.L., 1998, Missional church, William B. Eerdmans Publishing Company, Grand Rapids, MI.

Heward-Mills, D., 2012, 'Iron Sharpens Iron Ministers', paper presented at the Lighthouse Chapel International conference, Qodesh, Accra, Ghana, 25 July.

Hirsch, A., 2006, The forgotten ways: Reactivating the missional church, Brazos Press, Grand Rapids, MI.

Hirsch, A., 2014, 'The permanent revolution: Missional ministry for a missional church', paper presented at the New Community and Fresh Expressions of the Church conference, Department of Science of Religion and Missiology, Faculty of Theology, University of Pretoria, NG Kerk Moreleta Park, 09-11 March.

International Theological Commission, 1979, Catholic teaching on apostolic succession, viewed 19 February 2015, from http://www.vatican.va/roman_curia/ congregations/cfaith/cti_documents/rc_cti_1973_successione-apostolica_ en.html

Kaiser, W.C. Jr. \& Silva, M., 2007, Introduction to Biblical Hermeneutics, 2nd edn., Zondervan Publishing House, Grand Rapids, MI.

Kim, K., 2009, Joining in with the Spirit, Epworth Press, London.

Larbi, E.K., 2001, Pentecostalism: The eddies of Ghanaian Christianity, Blessed Publications, Accra.

Lorke, M. \& Werner, D. (eds.), 2013, Ecumenical vision for the 21st century, World Council of Churches, Switzerland.

McRae, W., 1976, The dynamics of spiritual gifts, Zondervan Publishing House, Grand Rapids, MI.

Moreau, S.A., 2000, Evangelical dictionary of world missions, Baker Books, Grand Rapids, Ml.

Roxburgh, A.J., 1997, The missionary congregation, leadership and liminality, Trinity, Harrisburg, PA.

Roxburgh, A.J., 1998, 'Equipping God's people for mission', in D. Guder (ed.), A vision for the sending of the church in North America, D. Guder (ed.), pp. 183-220, William B. Eerdmans Publishing Company, Grand Rapids, MI.

Sweet, L., 2004, Summoned to lead, Zondervan Publishing House, Grand Rapids, MI.

The Apostolic Church, Ghana, 2015, Leadership, viewed 24 March 2015, from http://80.theapostolicchurch.org.gh/leadership/

The Church of Pentecost, 2010, Constitution, Pentecost Press Ltd., Accra.

The Church of Pentecost, 2013, Vision, viewed 16 October 2013, from http:// thecophq.org/index.php/the-church/vision-2013

Third Lausanne Congress on World Evangelization, 2010, Cape Town Commitment viewed 16 October 2013, from http://www.lausanne.org/gatherings/congress/ cape-town-2010-3

Van Kooten, J. \& Barrett, L.Y, 2004, 'Missional authority', in L.Y. Barrett (ed.), Treasure in clay jars: Patterns in missional faithfulness, pp. 139-148, William B. Eerdmans Publishing Company, Grand Rapids, MI.

Van Rheenen, G., 1996, Biblical foundations and contemporary strategies: Missions, Zondervan Publishing House, Grand Rapids, MI.

Wagner, C.P., 1994a, Your church can grow, Regal Books, Ventura, CA.

Wagner, C.P., 1994b, Your spiritual gifts can help your church grow, Monarch Publications Ltd., Great Britain.

Wagner, C.P., 2000, Apostles and prophets: The foundation of the church, Regal Books, Ventura, CA.

Walls, A. \& Ross, C. (eds.), 2008, Mission in the 21st century: Exploring the five marks of global mission, Darton, Longman and Todd Ltd., London.

Wimber, J., 1986, 'Signs and wonders in the growth of the church', in P. Wagner, W. Arn \& E.L. Towns (eds.), Church growth: State of the art, p. 146, Tyndale Press, Wheaton, IL.

Witherington, B., 2007, The Letter to Philemon, the Colossians, and the Ephesians, William B. Eerdmans Publishing Company, Grand Rapids, MI.

Woodward, J.R., 2012, Creating a missional culture: Equipping the church for the sake of the world, InterVarsity, Downers Grove, IL. 